\title{
Editor's Note on Volume 7 Issue 6
}

\section{Venkateswarlu Chamcha*}

University of Louisiana, USA

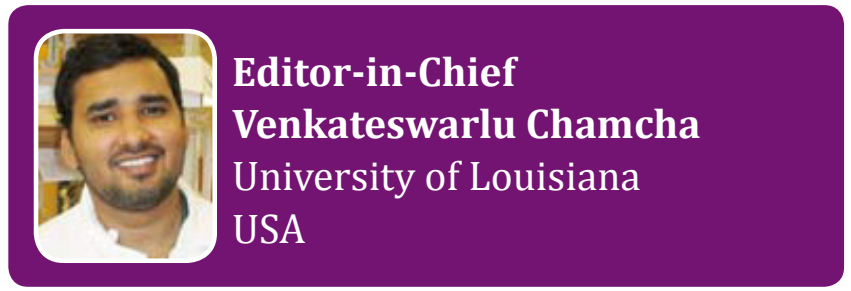

\section{Introduction}

I am sure you all agree with the bigger issue of HIV being the largest damage-causing agents to the human beings and taking away lot of resources from humans, especially from people who are living in African and sub-Saharan countries. Several efforts have been made to prevent the virus spread by various interventions such as using condom, pre-exposure prophylaxis (PrEP) and some of these have ben paying off to some extend in reducing newer infections. The other interventions that really working in expanding the life expectancy in HIV infected individuals are Antiretroviral Therapy (ART). However, it is almost unanimously agreed fact that, a potential vaccine for HIV is only the way to end this pandemic and we are too far away from reaching this goal. Keeping these things in mind, current issue focused on safe and effective vaccine approaches such as using probiotics, therapeutic interventions and some socio-economic issues.

\section{In this Issue}

Abiodun et al. reported and highlighted the importance to design interventions that increase awareness of sexual and reproductive health issues among Nigerian adolescent school children [1]. Zekeri, also, reported on one of the very important socio-economic issues, i.e., food insecurity and coping strategies among African American women living with HIV/AIDS in rural Alabama [2]. On the other hand, there are very comprehensive analyses on using maraviroc for keeping low virus copies, and a review on HIV-1 protease inhibitors are equally important have been reported [3]. Finally, in this issue, we end with a very nice commentary on tools implemented to study the risk assessment of cardiovascular diseases among HIV-infected patients [4]. Hope readers find this issue one of the very useful resources.

\section{References}

1. Abiodun $O$, Abiodun OO, Ani F, Sotunsa $O$ (2016) Sexual and reproductive health knowledge and service utilization among in-school rural adolescents in Nigeria. J AIDS Clin Res 7: 576.

2. Zekeri AA (2016) Food Insecurity and coping strategies among african american women living with hiv/aids on antiretroviral therapy in rural Alabama. J AIDS Clin Res 7: 582

3. Le Dû D, Marigot-Outtandy D, Mathez D, Dupont C, Sow MS, et al. (2016) Maraviroc intensification in HIV-1 infected patients with persistant lowleve viremia. J AIDS Clin Res 7: 578.

4. Hickey A, Bagchi S (2016) Cardiovascular disease risk assessment tools in HIV-infected patients - are they adequate? J AIDS Clin Res 7: 583.
*Corresponding author: Dr. Venkateswarlu Chamcha, Ph.D, Department of Microbiology and Immunology, Emory Vaccine Center, Yerkes National Primate Research Center, Emory University, Atlanta, Georgia, USA 30329, Tel: 404727 1432; Fax: 404727 7768; E-mail: vchamch@emory.edu

Received July 14, 2016; Accepted July 15, 2016; Published July 22, 2016

Citation: Chamcha V (2016) Editor's Note on Volume 7 Issue 6. J AIDS Clin Res 7 e120. doi:10.4172/2155-6113.1000e120

Copyright: (C 2016 Chamcha V. This is an open-access article distributed under the terms of the Creative Commons Attribution License, which permits unrestricted use, distribution, and reproduction in any medium, provided the original author and source are credited. 